\title{
EFEKTIVITAS PENERAPAN MOBILE APPLICATION "KAI ACCESS" OLEH KONSUMEN DI PT. KERETA API INDONESIA PERSERO DAERAH OPERASI 9 STASIUN JEMBER
}

\author{
Ni Putu Ayu Wangi Diantini ${ }^{1}$, Sukidin ${ }^{1}$, Wiwin Hartanto ${ }^{1}$ \\ ${ }^{1}$ Program Studi Pendidikan, Fakultas Keguruandan Ilmu Pendidikan, Universitas Jember \\ E-mail: wangidiantini@gmail.com
}

\begin{abstract}
Abstrak
Suatu perusahaan akan berupaya meningkatkan kualitas pelayanan untuk masyarakat. Salah satu perusahaan yang sudah mengembangkan beberapa inovasi yaitu PT. Kereta Api Indonesia (Persero) dengan menciptakan mobile application "KAI Access" yaitu aplikasi yang digunakan untuk membeli tiket secara online tanpa harus mengantri diloket stasiun. Oleh karena itu tujuan penelitian ini adalah untuk mengetahui efektivitas penerapan mobile application "KAI Access" di Stasiun Jember yang mengacu pada 6 (enam) aspek penilaian yaitu kualitas sistem, kualitas informasi, kualitas pelayanan, penggunaan, kepuasan pengguna, manfaat bersih. Penelitian ini merupakan penelitian deskriptif kuantitatif bertujuan untuk mengetahui nilai variabel mandiri yaitu efektivitas penerapan mobile application "KAI Access" tanpa membuat suatu perbandingan atau menghubungkan dengan variabel lain. Populasi dalam penelitian ini yaitu seluruh penumpang kereta api yang menggunakan mobile application "KAI Access" di Stasiun Jember yang terdiri dri 87 responden. Metode pengumpulan data yang digunakan adalah kuesioner, wawancara dan observasi. Hasil penelitian menunjukkan bahwa efektivitas penerapan mobile application "KAI Access" oleh konsumen di PT. Kereta Api Indonesia (Persero) Daerah Operasi 9 Stasiun Jember dapat dikatakan sangat efektif. Hal ini dapat dilihat dari penilaian setiap sub variabel efektivitas yaitu kualitas sistem sebesar 85,28\%, kualitas informasi sebesar $81 \%$, kualitas pelayanan sebesar $80,85 \%$, penggunaan sebesar $86 \%$, kepuasan pengguna sebesar $82 \%$, manfaat bersih sebesar $80,25 \%$. Berdasarkan persentase nilai responden tersebut maka efektivitas penerapan mobile application "KAI Access" oleh konsumen di PT. Kereta Api Indonesia (Persero) Daerah Operasi 9 Stasiun Jember dinyatakan sangat efektif dimana termasuk dalam rentan nilai diatas $80 \%$.
\end{abstract}

Kata Kunci : Efektivitas, Mobile Application "KAI Access"

\section{PENDAHULUAN}

Perkembangan dan kemajuan Teknologi Informasi dan Komunikasi (TIK) sangat diperlukan guna untuk memudahkan dan menyelesaikan berbagai masalah yang dihadapi oleh manusia dengan cepat dan singkat. Adanya perubahan gaya hidup masyarakat yang lebih dinamis, kita dituntut untuk selalu, mengikuti perubahan perkembangan TIK, yang tidak terbatas oleh ruang dan waktu. Pemerintah juga turut serta mengikuti perkembangan TIK, karena mampu mengatasi masalah pemerintahan, demi tercapainya efektivitas dan efesinnya pelayanan. Salah satu cara agar hal tersebut terwujud dengan membuat kebijakan baru melalui adanya inovasi pelayanan khususnya dalam hal percepatan dan kemudahan layanan yang berguna bagi masyarakat maupun instansi itu sendiri.

Wujud keikutsertaan pemerintah dalam mengikuti perkembangan TIK yaitu mendukung adanya ekonomi digital. Konsep ekonomi digital pertama kali di perkenalkan oleh Don Tapscott (The Digital Economy,1995) dalam Sayekti (2018) yaitu sebuah sosiopolitik dan sistem ekonomi yang mempunyai karakteristik sebagai sebuah ruang intelijen, meliputi informasi, berbagai akses instrumen, kapasitas, dan pemrosesan informasi. Komponen dari ekonomi digital yang berhasil diidentifikasi pertama kali yaitu industri teknologi, informasi, dan komumikasi (TIK), aktivitas $e$ commerce, serta distribusi digital barang dan jasa. Di Indonesia ekonomi digital terus berkembang ditandai dengan penggunaan internet yang terus meningkat.

Bus dan kereta api merupakan transportasi darat yang paling sering digunakan oleh masyarakat Indonesia dalam memenuhi kebutuhannnya untuk berpindah dari satu tempat ke tempat 
lainnya. Salah satu motivasi pemerintah untuk memudahkan para pelanggan transportasi darat, laut, maupun udara yaitu dengan menciptakan tiket online sehingga para pengguna transportasi tidak kesulitan untuk mendapatkan tiket. Stasiun Jember merupakan stasiun terbesar yang berada dalam pengelolaan PT. Kereta Api Indonesia (Persero) Daerah Operasi 9. Stasiun-stasiun utama lainnya meliputi Stasiun Banyuwangi Baru, Stasiun Probolinggo, Stasiun Pasuruan, Stasiun Kalisat, dan Stasiun Kalibaru. PT. Kereta Api Indonesia meluncurkan suatu inovasi yaitu peluncuran mobile application "KAI Access", merupakan aplikasi yang dibuat untuk membeli tiket ataupun hanya mengecek jadwal kereta api secara online kapanpun dan dimanapun. (PT Kereta Api (Persero), (2018).

Calon penumpang menganggap pembelian tiket secara online lebih menghemat waktu dengan tidak perlu mengantri diloket pembelian tiket. Banyak layanan-layanan penjual tiket kereta api seperti traveloka, tiket.com, tokopedia, bukalapak, pegi-pegi, blibli tetapi perbedaannya dengan KAI Access yaitu pada saat melakukan pembayaran tidak dikenakan biaya administrasi, bisa melakukan pembatalan tiket dan ada promo-promo menarik yang menguntungkan pengguna kereta api. Pembelian tiket melalui mobile application "KAI Access" bisa dilakukan 90 hari sebelum keberangkatan dan calon penumpang bebas memilih tempat duduk yang diinginkan. Pembayaran, bisa memilih metode yang telah disediakan mulai dari pembayaran melalui ATM, payment point, minimarket, klikpay BCA dan visa atau master. Sebagai penyedia jasa perkereta-apian dengan berbagai inovasi yang telah dikembangkan dalam penjualan dan pembelian tiket, perlu adanya evaluasi terhadap suatu inovasi yang telah dikembangkan tersebut, apakah aplikasi ini efektif untuk kedepanya atau justru berdampak negatif terhadap perusahaan itu sendiri. Dari latar belakang diatas peneliti bermaksud untuk melakukan penelitian yang berjudul "Efektivitas Penerapan mobile application "KAI Access" Oleh Konsumen di PT. Kereta Api Indonesia (Persero) Daerah Operasi 9 Stasiun Jember.

\section{METODE PENELITIAN}

Jenis penelitian ini adalah penelitian deskriptif kuantitatif, yang digunakan untuk menggambarkan suatu keadaan atau kondisi guna untuk membuat gambaran, deskripsi, dan fatual mengenai masalah yang ada berdasarkan data-data. Penelitian ini dilakukan untuk mengetahui nilai variabel mandiri yaitu Efektivitas penerapan mobile application "KAI Access" tanpa membuat suatu perbandingan atau menghubungkan dengan variabel lain. Populasi dalam penelitian ini adalah seluruh penumpang kereta api yang menggunakan mobile application "KAI Access" di Stasiun Jember. Teknik sampel yang digunakan yaitu Simple Random Sampling. Sampel diambil secara acak, tanpa memperhatikan tingkatan yang ada dalam populasi, dan jumlah sampel sebanyak 87 responden. Metode pengolahan data pada penelitian ini yaitu editing, skoring dan tabulasi. Skoring pada item pernyataan kuesioner pada indikator masing-masing sub variabel dalam penelitian ini menggunakan skala Likert. Teknis analisis data menggunakan rumus yang dikemukakan oleh Ndraha dalam Makmur (2008) yaitu :

Efektivitas $=\frac{\text { Realisasi }}{\text { Target }} \times 100$

Efektifitas dapat diukur menggunakan standar sesuai dengan acuan Litbang Depdagri 1991 (Ayu;2017) seperti pada tabel berikut ini :

Tabel 2. Standar Ukuran Efektivitas Sesuai Acuan Litbang Depdagri

\begin{tabular}{ll}
\hline \multicolumn{1}{c}{ Rasio Efektivitas } & Tingkat Pencapaian \\
\hline Dibawah 40 & Sangat tidak efektif \\
\hline
\end{tabular}




\begin{tabular}{ll}
\hline $40-59.99$ & Tidak Efektif \\
\hline $60-79.99$ & Cukup Efektif \\
\hline Diatas 80 & Sangat Efektif \\
\hline
\end{tabular}

sumber : Litbang Depdagri, (1991) (Ayu;2017)

\section{HASIL DAN PEMBAHASAN \\ Hasil Penelitian}

Berdasarkan hasil penelitian tentang Efektivitas Penerapan Mobile Application "KAI Access" oleh Konsumen di PT. Kereta Api Indonesia (Persero) Daerah Operasi 9 Stasiun Jember diperoleh hasil sebagai berikut :

Tabel 3. Hasil Penelitian Efektivitas Mobile Application "KAI Access"

\begin{tabular}{clcc}
\hline No & Sub Variabel & Persentase & Kategori \\
\hline 1 & Kualitas Sistem & $85,28 \%$ & Sangat Efektif \\
\hline 2 & Kualitas Informasi & $81 \%$ & Sangat Efektif \\
\hline 3 & Kualitas Pelayanan & $80,85 \%$ & Sangat Efektif \\
\hline 4 & Penggunaan & $86 \%$ & Sangat Efektif \\
\hline 5 & Kepuasan Pengguna & $82 \%$ & Sangat Efektif \\
\hline 6 & Manfaat-manfaat Bersih & $80,25 \%$ & Sangat Efektif \\
\hline
\end{tabular}

\section{Kualitas Sistem (System Quality)}

Pada sub variabel kualitas sistem (system quality) hasil penelitian sebesar 85,28\%. Ada beberapa indikator yang digunakan untuk mengukur seberapa besar kualitas sistem dari mobile application "KAI Access" ada empat indikator yang digunakan yaitu meliputi kemudahan untuk digunakan (easy of use), kecepatan akses (response time), keandalan sistem (reability), fleksibilitas sistem (flexibility). Pengguna mobile application "KAI Access" mengganggap bahwa kualitas sistem aplikasi ini sangat baik. Dari keempat indikator sub variabel kualitas informasi yang memiliki persentase tertinggi yaitu indikator kemudahan untuk digunakan (easy of use) dan indikator fleksibilitas sistem (flexibility), kedua indikator memiliki persentase tertinggi karena responden menganggap keunggulan dari aplikasi ini yaitu mudah digunakan dan bisa diakses dimana saja asalkan adanya jaringan internet yang memadai.

\section{Kualitas Informasi (Information Quality)}

Pada sub variabel kualitas informasi (information quality) memiliki hasil perhitungan penelitian sebesar $81 \%$, terdapat lima indikator yang digunakan untuk mengukur kualitas informasi yang dihasilkan oleh mobile application "KAI Access" yang meliputi kelengkapan (completeness), relevan (relevance), akurat (accurate), ketepatan waktu (timeliness), penyajian informasi (format). Responden berpendapat bahwa kualitas informasi yang di hasilkan oleh mobile application "KAI Access" sudah baik dan memberikan manfaat bagi penggunanya. Dari kelima indikator dari sub variabel kualitas informasi (information quality) yang memiliki persentase paling tinggi yaitu indikator penyajian informasi (format), hal ini dikarenakan mobile application "KAI Access" memiliki penyajian informasi yang tepat, sehingga pengguna mudah memahami informasi yang disajikan.

\section{Kualitas Layanan (Service Quality)}

Pada sub variabel kualitas layanan (service quality) hasil perhitungannya sebesar $80,85 \%$. Variabel ini digunakan untuk mengukur kualitas layanan yang diberikan oleh mobile application "KAI Access". Ada beberapa indikator yang digunakan untuk menguji kualitas layanan dari aplikasi ini meliputi jaminan (assurance), empati (emphaty), kecepatan respon (quick responsiviveness). Hal ini menunjukkan kualitas layanan (Service Quality) mobile application "KAI Access" sudah baik. Ketiga indikator dari sub variabel kualitas layanan (service quality) yang memiliki persentase tertinggi yaitu indikator jaminan, hal ini dikarenakan pengguna merasa yakin dengan informasi yang diperoleh karena bebas dari bahaya dan resiko keraguan-keraguan. 


\section{Penggunaan (Use)}

Pada sub variabel penggunaan (use) digunakan untuk mengukur seberapa banyak pengguna yang menggunakan mobile application "KAI Access", karena jika semakin banyak pengguna yang bergantung dengan aplikasi ini maka dapat diakatakan sistem ini berkualitas. Adapun hasil perhitungan penelitian sub variabel ini sebesar $86 \%$. Indikator pada sub variabel ini yaitu intensitas pengguna. Indikator intensitas pengguna ini menjelaskan jumlah pengguna yang menggunakan mobile application "KAI Access". Pengguna berasumsi bahwa dengan adanya aplikasi ini dapat membantu pekerjaan karena dapat memperoleh tiket tanpa perlu ke loket stasiun.

\section{Kepuasan Pengguna (User Satisfaction)}

Pada sub variabel kepuasan pengguna (user satisfaction) ini digunakan untuk mengukur kepuasan pengguna setelah menggunakan mobile application "KAI Access", hasil perhitungan penelitian variabel ini sebesar $82 \%$. Adapun beberapa indikator yang digunakan untuk menguji kepuasan pengguna yaitu kebutuhan terpenuhi dan rasa bangga. Pengguna KAI Access merasa sangat puas dengan kualitas dan layanan yang diberikan. Dari kedua indikator sub variabel kepuasan pengguna (user satisfaction) yang memiliki persentase paling tinggi yaitu indikator kebutuhan terpenuhi, hal ini dikarenakan pengguna merasa kebutuhannya terpenuhi oleh adanya mobile application "KAI Access".

\section{Manfaat Bersih (Net Benefit)}

Pada sub variabel manfaat bersih (net benefit) digunakan untuk mengukur manfaat-manfaat positif yang ada pada mobile application "KAI Access" sehingga manfaat positif ini berdampak pada pengguna dan organisasi, hasil penelitian sebesar $80.25 \%$. Adapun beberapa indikator yang digunakan untuk menguji sub variabel ini yaitu bermanfaat (usefull) dan mempertinggi efektivitas (enchance efectiveness). Pengguna mobile application "KAI Access" setuju bahwa aplikasi ini dapat meningkatkan pengetahuan pengguna dan mengurangi waktu dalam pencarian atau pembelian tiket kereta api. Dari kedua indikator sub variabel manfaat bersih (net benefit) yang memiliki persentase tertinggi yaitu indikator mempertinggi efektivitas (enchange efectiveness), hal ini dikarenakan dapat mempertinggi efektivitas pengguna dan organisasi atau perusahaan.

\section{Pembahasan}

Penelitian dengan judul "Efektivitas Penerapan Mobile Application "KAI Access" oleh Konsumen di PT. Kereta Api Indonesia (Persero) Daerah Operasi 9 Stasiun Jember" bertujuan untuk mengetahui tingkat efektivitas Penerapan Mobile Application "KAI Access dengan berpedoman pada model keberhasilan sistem informasi yang dikemukakan oleh William H. Delone dan Ephraim R. McLean.

Sub variabel pertama yaitu kualitas sistem menunjukkan hasil sebesar 85,25\% termasuk kedalam kategori sangat efektif. Hal ini menunjukkan kualitas sistem dari mobile application "KAI Access" sudah baik. Responden berpendapat bahwa aplikasi ini mudah dioperasikan dan dipahami, dengan kemudahan tersebut responden atau pengguna merasa nyaman. Melayani kebutuhan pengguna tanpa ada masalah, tidak hanya untuk membeli tiket tetapi juga bisa sekedar untuk mengecek jadwal kereta api di seluruh Indonesia. Hasil penelitian juga menunjukkan bahwa responden menganggap aplikasi ini memiliki kecepatan akses yang baik, karena dapat melakukan penelusuran informasi secara cepat dan bisa diakses dimana saja asalkan ada jaringan internet yang baik. Sebagian kecil responden menganggap sistem ini cukup sulit digunakan karena mereka belum memahami cara penggunaannya, hal ini dipengaruhi oleh pengetahuan masyarakat terhadap kecanggihan teknologi masih kurang. Hasil penelitian ini sesuai dengan teori yang dikemukakan oleh Delone dan McLean (1992) bahwa kualitas sistem dapat dikatakan berkualitas apabila suatu sistem informasi tersebut mudah dipahami dan digunakan, memilik kecepatan akses, keandalan sistem yang baik, sistem yang fleksibilitas dan keamanan sistem yang baik.

Sub variabel kedua yaitu kualitas informasi, hasil perhitungan sebesar $81 \%$ termasuk kedalam kategori sangat efektif. Responden menganggap informasi yang disajikan dalam aplikasi ini sudah lengkap dan sesuai dengan yang dibutuhkan. Informasi yang disajikan tidak ambigu dan bebas dari kesalahan, sehingga informasi yang diberikan oleh aplikasi ini cukup akurat, tetapi ada beberapa 
pengguna yang berpendapat bahwa pada saat pembuatan akun baru sering terjadi kesalahan dan membuat pengguna kebingungan sehingga mereka harus mencoba kembali untuk membuat akun tersebut, jadi dapat disimpulkan bahwa walaupun sistem ini memiliki tingkat akurasi yang tinggi akan tetapi tetap memiliki kesalahan-kesalahan kecil atau error. Kemudian informasi yang disajikan selalu up to date atau selalu mendapat informasi yang terbaru mengenai jadwal kereta api di seluruh Indonesia ataupun jumlah kursi yang tersedia hal ini dikarenakan setiap waktu jumlah kursi kereta api selalu mengalami perubahan. Hal ini sejalan dengan pendapat yang dikemukakan oleh Delone dan McLean (1992) bahwa sistem informasi memiliki informasi yang berkualitas apabila informasi yang dihasilkan lengkap. Kualitas informasi dapat dikatakan baik apabila relevan atau sesuai dengan kebutuhan pengguna dan penyajian yang tepat.

Pada sub variabel ketiga yaitu kualitas pelayanan menunjukkan hasil perhitungan sebesar 80,85\% termasuk kedalam kategori sangat efektif. Responden menganggap pelayanan yang diberikan sudah sesuai dengan apa yang dibutuhkan pengguna karena adanya kecepatan dan ketanggapan untuk merespon pada saat mengakses aplikasi ini, mereka merasa aman dalam mengakses informasi yang dibutuhkan karena semua tindakan pada penelusuran informasi dapat dipertanggungjawabkan dan memberikan informasi yang pasti tanpa ada keraguan-keraguan tetapi beberapa responden kurang setuju dengan pelayanan yang diberikan oleh aplikasi ini karena mereka mengeluhkan batas waktu pembayaran dalam pemesanan yang terlalu singkat. Jadi walaupun sistem ini sudah baik akan tetapi dari segi kualitas pelayanan, pengguna masih merasa ada kekurangan. Hal ini sesuai dengan teori yang dikemukakan oleh Delone dan McLean (2003) bahwa suatu sistem informasi dikatakan efektif apabila pengguna-pengguna sistem informasi merasa puas atas pelayanan yang diberikan, dimana kualitas pelayanan tersebut dapat dinilai dari segi kecepatan respon, jaminan atau bebas dari bahaya dan keraguan-keraguan, empati atau rasa bangga telah menggunakan suatu sistem informasi tersebut.

Sub variabel keempat yaitu penggunaan menunjukkan hasil perhitungan sebesar $86 \%$ termasuk kedalam kategori sangat efektif. Sub variabel ini adalah sub variabel tertinggi diantara 6 sub variabel yang ada. Hal ini menunjukkan responden selalu memesan atau membeli tiket melalui mobile application "KAI Access", responden menganggap membeli tiket melalui aplikasi ini lebih efektif dan efesien karena tidak perlu memesan langsung ke stasiun, cukup melalui aplikasi ini dengan memasukkan data diri, mengisi stasiun keberangkatan, stasiun tujuan dan waktu keberangakatan, tiket kereta api sudah bisa dimiliki oleh pengguna. Hasil penelitian ini sejalan dengan teori yang dikemukakan oleh Delone \& McLean (2003) bahwa suatu sistem informasi dapat dikatakan berkualitas apabila sistem tersebut banyak pengguna yang menggunakan, menimbulkan rasa ketergantungan terhadap sistem tersebut dan dapat membantu pekerjaan pengguna sesuai dengan yang dibutuhkan.

Sub variabel kelima yaitu kepuasan pengguna, hasil perhitungan sub variabel ini menunjukkan persentase sebesar $82 \%$ dan termasuk kedalam kategori sangat efektif. Hal ini menunjukkan, responden merasa puas dengan kualitas dan layanan yang disajikan oleh mobile application "KAI Access" karena memberikan informasi yang bermanfaat bagi responden dan membantu memperoleh informasi sesuai dengan yang dibutuhkan. Hal ini sejalan dengan pendapat yang dikemukakan oleh Livari (2005) bahwa sebuah sistem informasi yang dapat memenuhi kebutuhan pengguna akan dapat meningkatkan kepuasan pengguna.

Sub variabel terakhir yaitu manfaat-manfaat bersih, maksud dari manfaat-manfaat bersih atau keuntungan bersih yaitu keuntungan responden atau pengguna dalam menggunakan mobile application "KAI Access" hasil perhitungan menunjukkan sebesar 80,25\% dan termasuk kedalam kategori sangat efektif. Sub variabel ini merupakan sub variabel terendah dari ke 6 sub variabel yang ada. Sub variabel manfaat-manfaat bersih menjadi sub terendah karena responden menganggap aplikasi ini tidak begitu banyak memberikan pengetahuan tetapi dapat mengurangi waktu pada saat informasi terkait dengan tiket kereta api.

\section{PENUTUP}

Berdasarkan tujuan penelitian yang telah dilakukan untuk mengetahui tingkat efektivitas penerapan mobile application "KAI Access" oleh konsumen di PT. Kereta Api Indonesia (Persero) 
Daerah Operasi 9 Stasiun Jember, menunjukkan bahwa efektivitas penerapan mobile application "KAI Access" oleh konsumen di PT. Kereta Api Indonesia (Persero) Daerah Operasi 9 Stasiun Jember dari keenam sub variabel sangat baik. Kesimpulan yang di dapat dari hasil perhitungan efektivitas dalam penelitian ini adalah efektivitas penerapan mobile application "KAI Access" oleh konsumen di PT. Kereta Api Indonesia (Persero) daerah operasi 9 Stasiun Jember dapat dinyatakan sangat efektif. Hal ini dibuktikan oleh hasil perhitungan jawaban responden dari keenam sub variabel hasil rata-rata sebesar $82.56 \%$.

Berdasarkan hasil penelitian Efektivitas Penerapan Mobile Application "KAI Access" oleh Konsumen di PT. Kereta Api Indonesia (Persero) Daerah Operasi 9 Stasiun Jember, peneliti menyarankan sebaiknya PT. Kereta Api Indonesia (Persero) perlu melalukan sosialisasi lebih dalam terkait dengan pembuatan akun baru dari aplikasi Mobile Application "KAI Access", karena ada beberapa pengguna yang masih menggeluhkan tentang cara pembuatan akun baru. Kemudian perlu memperbaiki durasi pembayaran saat pembelian tiket tiket kereta agar waktunya diperpanjang sehingga memberikan kenyamanan bagi pengguna Mobile Application "KAI Access".

\section{DAFTAR PUSTAKA}

Ayu. 2017. Analisis Pengukuran Tingkat Efektivitas dan Efesiensi Sistem Informasi Manajemen Surat STIKOM Bali. Vol.11, No.2

DeLone and Mclean. 2003. The DeLone and McLean Model of Information Systems Success: A TenYear Update. Vol.19, No.4

Livari. 2005. An Empirical Test of the Delone-McLean Model Of Information System Success. Vol. 36, No.3

Makmur, Syarif. 2008. Pemberdayaan Sumber Daya Manusia dan Efektivitas Organisasi. Jakarta: PT. Raja Grafindo Persada

Neolaka. 2016.Metode Penelitian dan Statistik. Bandung 40252. PT. Remaja Rosdakarya.

Sayekti. 2018. Tantangan Perkembangan Ekonomi Digital Di Indonesia. Vol. X, No.05 